\title{
THE THROMBOPLASTIC ACTIVITY OF RUSSELL'S VIPER VENOM AND ITS RELATIONSHIP TO FACTOR VII
}

\author{
BY \\ J. S. JENKINS \\ From the Department of Pathology, St. Bartholomew's Hospital, London
}

(RECEIVED FOR PUBLICATION JANUARY 5, 1954)

The thromboplastic activity of Russell's viper venom was first recognized to be of practical value when it was used by Macfarlane and Barnett (1934) as a powerful local haemostatic agent in the treatment of haemophilia.

Fullerton (1940) substituted Russell's viper venom for rabbit-brain thromboplastin in his modification of Quick's one-stage prothrombin time, since viper venom could be obtained in a more convenient and more stable form than brain extract It soon became apparent, however, that the two methods gave widely different results. Wilson (1947) and many other workers found that in cases treated with dicoumarol much higher plasma prothrombin values were obtained with venom than with brain thromboplastin, and, in fact, Fullerton's modification could be dangerous, since it gave inadequate warning of prothrombin values low enough to cause haemorrhage.

It has been shown by Macfarlane, Trevan, and Attwood (1941) that a lipoid substance in the plasma is necessary for the action of viper venom, and an excess of lipoid, such as occurs after a fatty meal, shortens the prothrombin time with venom but not with brain thromboplastin (Fullerton and Anastasopoulos, 1949).

A further source of the difference in action of the two thromboplastins became apparent when it was recognized that the one-stage prothrombin time measured not only prothrombin but also the two accelerator factors which have been termed Factor V (Owren, 1947) and Factor VII (Koller, Loeliger, and Duckert, 1951).

It seemed possible that venom and brain extract reacted to these factors in a different manner, and the relationship of Factor VII to these thromboplastins is the subject of the following experiments.

\section{Methods}

Quick's One-stage Prothrombin Time.-Quick's onestage prothrombin times were carried out using " difco" rabbit brain thromboplastin.
Russell's Viper Venom Modification.-Oxalated plasma, $0.1 \mathrm{ml}$., and $0.1 \mathrm{ml}$. of 1 in 20,000 solution of " stypven " brand of Russell's viper venom were incubated at $37^{\circ} \mathrm{C}$. Then $0.1 \mathrm{ml}$. of $0.025 \mathrm{M}$. solution of calcium chloride was added and the time recorded for fibrin particles to appear.

Factor VII.-Factor VII was obtained from normal serum by the addition of an equal quantity of $0.008 \mathrm{M}$. tricalcium phosphate suspension and the adsorbed Factor VII was obtained in solution by elution of the precipitate with $0.2 \mathrm{M}$. sodium citrate in a volume one-tenth of the original serum.

$\mathrm{Ca}_{3}\left(\mathrm{PO}_{4}\right)_{2}$-plasma.- $\mathrm{Ca}_{3}\left(\mathrm{PO}_{4}\right)_{2}$-plasma was obtained by centrifuging normal oxalated plasma that had been treated by an equal quantity of $0.008 \mathrm{M}$. tricalcium phosphate.

\section{Experimental Results}

Effect of Russell's Viper Venom (Stypven) on Tromexan Plasma.- It has been shown by Hunter and Tudhope (1953) that the main action of the anti-coagulant drug "tromexan" is to depress Factor VII and not prothrombin, at least in the initial period of treatment. Prothrombin times were carried out on tromexan plasma using " difco " and "stypven" thromboplastins in parallel, and the results expressed as " prothrombin " percentage by reference to saline dilution curves. Plasmas were investigated on different days after the beginning of therapy as shown in Table $I$.

TABLE I

ONE-STAGE PROTHROMBIN TEST ON TROMEXAN PLASMA

\begin{tabular}{|c|c|c|c|c|c|c|c|c|}
\hline & Day & 2 & 3 & 4 & 5 & 8 & 11 & 16 \\
\hline $\begin{array}{l}\text { Prothrombin } \\
(\%)\end{array}$ & $\begin{array}{l}\text { Difco } \\
\text { Stypven }\end{array}$ & $\begin{array}{r}23 \\
100\end{array}$ & $\begin{array}{l}12 \\
33\end{array}$ & $\begin{array}{l}34 \\
75\end{array}$ & $\begin{array}{l}36 \\
80\end{array}$ & $\begin{array}{l}18 \\
55\end{array}$ & $\begin{array}{l}19 \\
29\end{array}$ & $\begin{array}{l}16 \\
14 \cdot 5\end{array}$ \\
\hline
\end{tabular}

It can be seen that much higher values are given with "stypven" than with " difco," especially in the earlier period of therapy. The closer approximation of the two methods in the later days may be due to the fact that prothrombin also is reduced if tromexan is continued for this length of time. 
Hunter and Tudhope (1953) have shown that normal serum containing Factor VII has an accelerator action on tromexan plasma and the following experiment shows that " stypven" possesses similar accelerator activity. Tromexan plasma was mixed with stypven solution, 1 in 20,000 , in the proportion of 9 to 1 and prothrombin times were carried out by Quick's method on successive days of therapy (Table II).

TABLE II

ACCELERATOR ACTION OF STYPVEN ON TROMEXAN PLASMA

\begin{tabular}{|c|c|c|c|c|c|c|c|}
\hline Day: & 0 & 1 & 2 & 3 & 5 & 6 & 7 \\
\hline $\begin{array}{l}\text { Prothrombin time in secs. (Quick): } \\
\text { Tromexan plasma } \ldots \\
90 \% \text { tromexan plasma }+10 \% \\
\text { "stypven" } \ldots\end{array}$ & $\begin{array}{r}12 \\
8\end{array}$ & $\begin{array}{r}16 \cdot 5 \\
8 \cdot 5\end{array}$ & $\begin{array}{l}27 \\
9 \cdot 5\end{array}$ & $\begin{array}{l}20 \\
9 \cdot 5\end{array}$ & $\begin{array}{l}21 \\
10\end{array}$ & $\begin{array}{l}21 \\
9 \cdot 5\end{array}$ & $\begin{array}{c}20 \\
12 \cdot 5\end{array}$ \\
\hline
\end{tabular}

The powerful accelerator action produced by $10 \%$ of 1 in 20,000 solution of "stypven " is again most marked in the earlier days of therapy.

Effect of Stypven on Plasma of Congenital Factor VII Deficiency.-The case of congenital Factor VII deficiency used in these experiments has been fully described elsewhere (Jenkins, 1954).

One-stage prothrombin times were measured on several occasions on plasma from this case using "difco" and "stypven" in parallel (Table III). For purposes of comparison the prothrombin times are expressed as "prothrombin" percentage by reference to dilution curves, although it has been shown by the two-stage prothrombin test that in reality only Factor VII is deficient.

TABLE III

ONE-STAGE PROTHROMBIN TEST ON PLASMA OF CONGENITAL FACTOR VII DEFICIENCY

\begin{tabular}{l|l|l|l|l|l|l}
\hline Prothrombin (\%) .. & $\begin{array}{l}\text { Difco } \\
\text { Stypven }\end{array}$ & 83 & $\mathbf{8 0}$ & 15 & 20 & 9 \\
& & 800 & 78 & 100 \\
\hline
\end{tabular}

It will be seen that " stypven " gives no indication of Factor VII deficiency and, in fact, the prothrombin values given by "stypven" corresponded closely to those obtained by the two-stage test in this case.

The corrective action of "stypven" on the prothrombin time was demonstrated by mixing the patient's plasma with "stypven" in the proportion of 9 to 1 and measuring Quick's prothrombin times. The results were compared with the corrective effect of similar amounts of normal serum and normal plasma, both of which contain Factor VII or its precursor (Table IV).

The powerful effect of a 1 in 20,000 solution of "stypven" is shown and even in a dilution of 1 in 200,000 the action is comparable with normal
TABLE IV

ACCELERATOR ACTION OF STYPVEN ON PLASMA FROM CONGENITAL FACTOR VII DEFICIENCY

Mixtures (Parts)

\begin{tabular}{c|c|c|c|c|c}
\hline $\begin{array}{c}\text { Patient's } \\
\text { Plasma }\end{array}$ & $\begin{array}{c}\text { Stypven } \\
1 / 20,000\end{array}$ & $\begin{array}{c}\text { Stypven } \\
1 / 200,000\end{array}$ & $\begin{array}{c}\text { Normal } \\
\text { Serum }\end{array}$ & $\begin{array}{c}\text { Normal } \\
\text { Plasma }\end{array}$ & $\begin{array}{c}\text { Prothro mbin } \\
\text { Time (sec.) }\end{array}$ \\
\hline & & & & 1 & 17 \\
1 & & & & & 55 \\
9 & 1 & 1 & & & 10 \\
9 & & & 1 & 1 & 17 \\
9 & & & & 1 & 23 \\
\hline
\end{tabular}

serum and greater than normal plasma in correcting the prothrombin time of Factor VII-deficient plasma.

Comparison of the Properties of "Stypven Accelerator" and Factor VII.-Factor VII is completely absorbed from serum by $\mathrm{Ca}_{3}\left(\mathrm{PO}_{4}\right)_{2}$ and can be recovered by elution with sodium citrate. Stypven in 1 in 20,000 solution was treated in a similar manner in order to discover whether its accelerator activity also possessed these properties.

The $\mathrm{Ca}_{3}\left(\mathrm{PO}_{4}\right)_{2}$-treated serum, the $\mathrm{Ca}_{3}\left(\mathrm{PO}_{4}\right)_{2}$ "stypven," the eluted Factor VII, and the eluted "stypven" accelerator were each tested in turn for accelerator activity. For this purpose a $10 \%$ dilution of normal plasma in $\mathrm{Ca}_{3}\left(\mathrm{PO}_{4}\right)_{2}$-treated plasma was made, thereby ensuring an excess of Factor V, and this was mixed with $10 \%$ of the solution to be tested. Prothrombin times were measured in the usual manner and the results are shown in Table V.

TABLE V

COMPARISON OF STYPVEN ACCEI.ERATOR AND FACTOR VII
Mixtures (Parts)

\begin{tabular}{|c|c|c|c|c|c|c|}
\hline 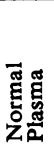 & 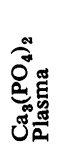 & 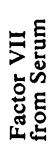 & 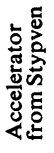 & 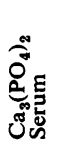 & 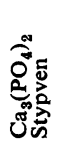 & 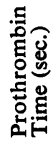 \\
\hline $\begin{array}{l}1 \\
1 \\
1 \\
1 \\
1\end{array}$ & $\begin{array}{l}9 \\
8 \\
8 \\
8 \\
8\end{array}$ & 1 & 1 & 1 & 1 & $\begin{array}{l}28 \\
16 \\
14 \\
29 \\
23\end{array}$ \\
\hline
\end{tabular}

It can be seen that the accelerator factor of $\frac{D}{O}$ "stypven" can be adsorbed by $\mathrm{Ca}_{3}\left(\mathrm{PO}_{4}\right)_{2}$ and eluted by sodium citrate in a similar manner to $N$ Factor VII except that when a 1 in 20,000 solution $N$ of "stypven" is treated with the same amount of $\mathcal{N}$ $\mathrm{Ca}_{3}\left(\mathrm{PO}_{4}\right)_{2}$ as is used for serum, the adsorption of $\mathrm{W}$ accelerator from "stypven " is not quite as complete as that of Factor VII from serum.

\section{Discussion}

These experiments show that Russell's viper venom has a powerful accelerator action similar in many respects to that of Factor VII and in view of their 
widely different origins this close similarity is somewhat remarkable.

It is now believed that the action of Factor VII in blood coagulation is concerned with the formation of plasma thromboplastin (Biggs, Douglas, and Macfarlane, 1953) and it appears to be identical with the "co-thromboplastin" described by Mann and Hurn (1951).

Brain thromboplastin requires Factor VII for its action, whereas Russell's viper venom is more complete in its thromboplastic activity because of the co-thromboplastin or accelerator which it contains. This property explains the powerful haemostatic action of venom but renders it insensitive to the reduction of Factor VII which occurs after the administration of dicoumarol or tromexan. For this reason, "stypven" is useless in the control of treatment with these drugs.

Since rabbit brain extract and viper venom differ in this manner, it is possible that the divergent results obtained by various workers using other sources of thromboplastin, such as human placenta or ox lung, are related to the nature or quantity of the co-thromboplastin factors in these tissue extracts.
The action of rabbit brain extract is the best known of all these tissue preparations and for this reason it is to be preferred for general use.

\section{Summary}

Russell's viper venom is shown to have a powerful accelerator action as part of its thromboplastic activity.

The accelerator is closely similar to Factor VII and is probably a co-thromboplastin.

Differences in the thromboplastic activity of other tissue extracts may be related to the co-thromboplastin present.

I wish to thank Dr. H. F. Brewer for his encouragement while carrying out this work.

\section{REFERENCES}

Biggs, R., Douglas, A. S., and Macfarlane, R. G. (1953). J. Phy'siol. Lond., 119, 89.

Fullerton, H. W. (1940). Lancet, 2, 195.

and Anastopoulos, G. (1949). Brit. med. J., 2, 1492.

Hunter, R. B., and Tudhope, G. R. (1953). Lancet, 1, 821.

Jenkins, J. S. (1954). Journal of Clinical Pathology, 7, 29.

Koller, F., Loeliger, A., and Duckert, F. (1951). 'Acta Haemat., Basel, 6, 1.

Macfarlane, R. G., and Barnett, B. (1934). Lancet, 2, 985.

Trevan, J. W., and Attwood, A. M. P. (1941). J. Physiol., Lond., 99, 7P.

Mann, F. D., and Hurn, M. (1951). Amer. J. Physiol., 164, 105.

Owren, P. A. (1947). Lancet, 1, 446.

Wilson, S. J. (1947). Proc. Soc. exp. Biol., N.Y., 66, 126. 